\title{
KONSTRUKSI MAKNA DAMPAK MEDIA INTERNET PENGGUNAAN MEDIA INTERNET OLEH PELAJAR DI KOTA PURWOKERTO KABUPATEN BANYUMAS (Studi Deskriptif Kualitatif Para Pelajar di Kota Purwokerto Kabupaten Banyumas)
}

\author{
Adhi Iman Sulaiman \\ Staf Dosen FISIP Universitas Jenderal Soedirman \\ Jl. Prof. Dr. Boenyamin No. 993 Purwokerto Jawa Tengah 53122 \\ (Naskah diterima 13 November 2010 - Revisi 2 Maret 2011)
}

\begin{abstract}
Abstrak
Penelitian ini untuk mengonstruksi dampak media internet dari para pelajar di Kota Purwokerto. Hasilnya bahwa para pelajar memaknai media internet sebagai media hiburan, media interaksi dan sebagai media yang menyediakan sumber ilmu pengetahuan dan wawasan. Sehingga pelajar menganggap media internet lebih banyak dampak positifnya. Namun para pelajar juga menyadari dampak negatif media internet seperti pornografi berupa gambar dan video, juga aksi kekerasan lewat media online game yang menyebabkan ketergantungan sehingga lupa waktu menghabiskan waktu belajar. Warung internet (Warnet) dikonstruksi sebagai tempat yang sangat dominan untuk mengakses internet secara bebas, murah dan mudah. Bahkan warnet juga diketahui sebagai tempat yang dimanfaatkan melakukan tindakan asusila, dikarenakan sekat Kamar Bilik Umum (KBU) yang sangat tertutup. Maka pelajar menyadari perlunya warnet sehat dengan KBU yang terbuka KBU-nya, ada jam pelayanan tertentu untuk para pelajar dan memblokir situs tertentu.

Maka antisipasi dampak negatif media internet bisa dilakukan dengan pendekatan sosiologis peran pemerintah, orang tua, dan pihak pendidikan. Pendekatan teknologi dengan software filter situs tertentu dan website filter serta website sehat. kemudian pendekatan hukum dengan membuat peraturan daerah (perda) seperti mengenai ijin pendirian serta oprasional warnet
\end{abstract}

Kata Kunci : media internet, dampak, antisipasi

\begin{abstract}
This research is to construct the impact of the Internet media from the students in the city of Purwokerto. The result is that the Students interpret the Internet as a medium of entertainment media, media interaction and as a medium that provides a source of knowledge and insights. So that students consider the Internet media more positive impact. But the students also realized the negative impact of the Internet media such as pornographic images and videos, as well onlinegame violence through the media and cause dependency, so forget the time spent studying. "Warung Internet" (Warnet) is constructed as a very dominant place to access the internet for free, cheap and easy. Even "Warnet" to be a place to perform immoral acts because of sekatting room or "Kamar Bilik Umum" (KBU) is very closed. So the students realize the need safe room on "Warnet" with an open KBU, certain service hours for students as well as blocking specific sites.

So anticipating the negative impact of internet media the government must be proactive by making local regulation (perda) on the permit and the rules of establishment and operations "warnet". The school also encourage socialization impact of the Internet media to students, including the role parents are still effectively in control of their children using the Internet media.
\end{abstract}

Keywords: internet media, impact, anticipation 


\section{PENDAHULUAN}

Fenomena yang sangat menggemparkan sekaligus memilukan yang terjadi pada awal bulan Juni 2010 ketika tersebar kasus "video panas" yang disinyalir mirip beberapa artis terkenal tersebar lewat media internet. Kasus tersebut mendapat sorotan serius dan menyedot perhatian berbagai kalangan, mulai dari instansi penegak hukum dalam hal ini kepolisian, kalangan advokat, praktisi hukum dan media massa serta kelompok masyarakat yang semuanya melakukan rekonstruksi atas kasus "video panas" di internet karena terjadi pelanggaran moral, etika, agama dan hukum. Kekhawatiran muncul khususnya terhadap generasi muda dalam hal ini pelajar yang tingkat peniruan (imitasi) atas sesuatu yang diidolakan seperti artis membawa pengaruh yang cukup besar. Sebagaimana data dari Komisi Perlindungan Anak Indonesia (KPAI) ada 33 kasus tindakan asusila akibat menonton "video panas" yang mirip dengan artis, pelakunya yaitu berusia antara 16 sampai 18 tahun yang merupakan usia remaja dan pelajar, sedangkan yang menjadi korbannya berusia 12 -14 tahun, data tersebut merupakan hasil laporan di berbagai daerah antara tanggal 14 - 23 Juni 2010. (Republika online 24 Juni 2010 dan detik news.com 1 Juli 2010)

Media internet menjadi dunia yang sangat menarik untuk remaja atau pelajar. Media internet juga menyediakan wahana kebebasan yang nyaris tanpa batas oleh jarak ruang, waktu serta kapanpun dan di manapun selama dapat mengakses internet. William Gibson mendefinisikan internet (cyberspace) sebagai halusinasi bersama atau simulasi dari jagat nyata (real world) ke jagat maya (virtual world). (Ratnasari, dalam Jurnal Mimbar, Vol 7, No 1, 2008)

Media massa salah satunya internet memberikan ruang publik yang demokratis bagi penggunanya (khalayak) untuk bisa memilah, memilih, ikut memberikan pendapat sebagai bentuk aspirasi dan opininya secara langsung (interaktif) atau tidak langsung. Kekuatan eksistensi dan peran media massa tersebut apa yang disebut McLuhan (Littlejohn, 2006 : 562), sebagai lingkungan global (global village), di mana masyarakat yang terbentuk dengan peran media massa serta dukungan teknologi informasi, dunia seakan sudah seperti tidak ada lagi batas jarak, ruang dan waktu. Pentingnya media massa merupakan sumber kekuatan dan alat kontrol, manajemen dan motivasi dalam masyarakat yang dapat didayagunakan sebagai pengganti kekuatan dan sumber daya lainnya.

Media internet bukan hanya memiliki dampak negatif, akan tetapi juga memiliki dampak positif seperti untuk dunia pendidikan, internet sudah menjadi tuntutan sekaligus kebutuhan yang berfungsi sebagai media dan metode pembelajaran serta sumber ilmu pengetahuan yang dapat diakses kapan saja dan di mana saja. UNESCO Asia dalam artikel Developing and Using Indicators of Information Communication of Technology (ICT) in Education mengatakan bahwa cukup penting untuk menguji indikator bahwa Teknologi Informasi dan Komunikasi (TIK) tidak hanya digunakan sebagai alat dasar operasional tetapi juga sebagai alat komunikasi dalam rangka mengembangkan kreativitas, interaksi, collaborative learning (belajar kelompok), berpikir kritis dan memecahkan masalah (www.jurnal nasional.com).

Berdasarkan latar belakang masalah pada penelitian ini, maka dapat dirumuskan permasalahan yaitu: bagaimana pemaknaan dampak media internet dari para pelajar di Kota Purwokerto Kabupaten Banyumas Provinsi Jawa Tengah?

Penelitian ini bertujuan untuk mengonstruksi makna dampak media internet dari para pelajar di Kota Purwokerto Kabupaten Banyumas Provinsi Jawa Tengah.

\section{LANDASAN KONSEP}

\section{Komunikasi Massa}

Pusat perhatian dalam pembahasan komunikasi massa adalah lembaga-lembaga media yang menyebarluaskan pesan-pesan yang memengaruhi dan mencerminkan budaya masyarakat. Media massa 
menyampaikan informasi secara bersamaan pada sejumlah besar audiens yang heterogen, dan menjadikan media sebagai bagian dari kekuatan institusional masyarakat. Rumusan klasik komunikasi massa mengatakan, ketika sebuah organisasi menggunakan teknologi sebagai media berkomunikasi dengan khalayak yang luas, maka terjadilah apa yang disebut sebagai komunikasi massa. (Baran dan Davis, 2003 : 10)

Berbagai definisi mengenai komunikasi massa, mengacu pada satu proses penyampaian ide atau pesan dari komunikator kepada komunikan melalui media massa. Proses komunikasi massa diawali oleh komunikator (sender) yang menyampaikan message kepada komunikan (receiver) melalui media (channel) dan kemudian komunikan memberikan feed back atas message yang diterimanya kepada komunikator. Dalam hal ini komponen komunikasi massa adalah komunikator, message, channel/media, komunikan dan efek. (Schramm dalam McQuail, 1987 : 2324). Sebuah definisi sederhana pun dibuat, yang menyatakan komunikasi massa adalah komunikasi melalui media massa, baik cetak maupun elektronik. (Nurudin, 2004: 4)

Komunikasi massa merupakan sutu proses kontak hubungan dan atau interaksi di antara manusia dengan ciri antara lain lebih bersifat impersonal. Dalam arti, kontak hubungan dan atau interaksi tersebut tidak berlangsung secara tatap muka melainkan melalui perantaraan media (medium) seperti: surat kabar, majalah, televisi, video disk, dan lain-lain. Sifat lain dari hubungan antara pengirim dan penerima dalam komunikasi massa adalah impersonalitas yang bersumber dari adanya jarak fisik dan sosial antara kedua belah pihak. (McQuail, 1987: 3).

Jarak sosial yang ada berkenaan dengan hubungan yang tidak simetris (asimetris), walaupun pengirim tidak memiliki kekuasaan formal terhadap penerima, namun pengirim biasanya memiliki lebih banyak sumber daya, prestise, keahlian, dan otoritas sedangkan penerima hanya merupakan bagian dari khalayak luas. Penerima merasakan pengalaman dan memberikan reaksi secara bersama-sama dengan orang lain menurut pola tertentu yang dapat diperkirakan sebelumnya. Sementara komunikasi massa sendiri antara lain mempunyai ciri yaitu : (1) Diarahkan pada audiens yang secara relatif luas dan anonim. Komunikasi massa seringkali mencakup kontak secara serentak antara satu pengirim dengan banyak penerima. (2) Pesan disampaikan secara terbuka dan menciptakan pengaruh luas dalam waktu yang singkat dan bersifat sementara. Komunikatornya cenderung, atau beroperasi dalam sebuah organisasi yang kompleks dan melibatkan biaya yang besar.

\section{Fungsi Media Massa}

Media massa pada prinsipnya adalah segala sesuatu yang merupakan saluran dengan seseorang yang menyatakan gagasan, isi jiwa atau kesadarannya, yaitu melalui (1) media yang menyalurkan ucapan (the spoken words) lewat media dengar (the audial media) seperti radio; (2) media menyalurkan tulisan (the printed writing) lewat media pandang (the visual media) seperti surat kabar dan majalah; (3) media yang dapat menyalurkan gambar hidup dan suara atau audio visual media seperti televisi; (4) media yang dapat berinteraktif langsung seperti international network yaitu internet (Arifin, 2003: 94-95).

Menurut Sean MacBride (Effendy, 2005: 27) karena komunikasi massa merupakan bagian dari suatu bentuk komunikasi dengan media massanya yang dapat menjangkau khalayak yang luas, maka fungsi komunikasi juga menjadi fungsi komunikasi massa dengan media massanya yang dapat menjangkau khalayak yang amat luas baik lokal, nasional maupun internasional. Lebih lanjut MacBridge menyatakan apabila komunikasi dipandang dari arti yang luas, tidak hanya diartikan sebagai pertukaran berita dan pesan tetapi sebagai kegiatan individu dan kelompok mengenai tukar menukar data, fakta, dan ide, maka fungsinya dalam setiap sistem sosial diantaranya adalah: (1) Informasi ; Pengumpulan, penyimpanan, pemrosesan, penyebaran berita, data, gambar, fakta dan pesan, opini, komentar yang dibutuhkan agar orang dapat mengerti dan bereaksi secara jelas terhadap kondisi 
internasional, lingkungan dan orang lain dan agar dapat mengambil keputusan yang tepat. (2) Sosialisasi ; Penyediaan sumber ilmu pengetahuan yang memungkinkan orang bersikap dan bertindak sebagai anggota masyarakat yang efektif serta menyebabkan kesadaran diri akan fungsi sosialnya sehingga ia dapat aktif di dalam masyarakat. (3) Motivasi; menjelaskan tujuan setiap masyarakat jangka pendek maupun jangka panjang yang mendorong orang menentukan pilihannya, keinginannnya. Mendorong keinginan individu atau kelompok berdasarkan tujuan bersama yang akan dikejar. (4) Perdebatan dan diskusi; menyediakan media untuk saling menukar fakta yang diperlukan untuk memungkinkan persetujuan atau penyelesaian perbedaan pendapat mengenai masalah publik. Menyediakan bukti-bukti yang relevan yang diperlukan untuk kepentingan umum agar masyarakat lebih melibatkan diri dalam masalah yang menyangkut kegiatan bersama di tingkat internasional, nasional, dan lokal. (5) Pendidikan : pengalihan ilmu pengetahuan sehingga mendorong perkembangan intelektual, pembentukan watak, dan pendidikan ketrampilan serta kemahiran yang diperlukan pada semua bidang kehidupan.

Harold D. Lasswell (dalam Effendy, 2005 : 28) menyatakan proses komunikasi di masyarakat menunjukkan tiga fungsi (1) Pengamatan terhadap lingkungan (the surveillance of the environment), penyingkapan ancaman dan kesempatan yang memengaruhi nilai masyarakat dan bagianbagian unsur di dalamnya. (2) Korelasi unsurunsur masyarakat ketika menanggapi lingkungan (correlation of the components of society in making response to the environment). (3) Penyebaran warisan sosial (transmission of the social inheritance), di sini berperan para pendidik baik dalam peran rumah tangganya maupun di sekolah yang meneruskan warisan sosial kepada keturunan berikutnya.

\section{Media Internet}

Media internet disebut juga sebagai teknologi komunikasi baru sebagaimana menurut Baldwin et.al adalah sebuah metode baru dalam menyimpan, menyampaikan dan penerimaan informasi yang meliputi bentuk informasi apapun dari teknologi digital seperti world wide web (www), chatroom, radio dan televisi satelit. Begitupun menurut Ono W. Purbo (1999) bahwa banyak sekali aplikasi dan fasilitas yang terdapat dalam internet, seperti aplikasi dan fasilitas lain di internet yaitu surat elektronik (e-mail), mailing list (Millis) bercakap-cakap dengan fasilitas IRC (Internet Relay Chat), dan kelompok diskusi (Newsgroup) serta world wide web (www). Perkembangan selanjutnya aplikasi lain yang sangat digemari adalah friendster kemudian faceebook, dan twitter. (Baldwin et.al, 2004 : 246)

Penggunaan internet sebagaimana hasil riset yang dilakukan oleh Swa-Mark Lus \& Co (Athari, 2004 dalam Jurnal Vol. 3, No. 1) bahwa ada tiga kelompok pengguna internet berdasarkan lima waktu yang dipakainya yaitu : (1) Pengguna berat (heavy users) lebih dari 40 jam per bulan; (2) Pengguna sedang (medium user) 10 - 40 jam per bulan; (3) Pengguna ringan (light user) tidak lebih dari 10 jam per bulan. Hal tersebut menurut Quitter (dalam Nguyen dan Alexander, 1998: 103) bahwa komunikasi lewat media internet membuat orang terpikat untuk berkomunikasi secara intensif dan terus-menerus dalam frekuensi tertentu menghabiskan waktu tertentu pula untuk menggunakannya. Internet juga dapat menyebabkan penggunanya mengalami kecanduan. Rasa senang yang diperoleh dari berinternet menyebabkan seseorang lupa waktu, sehingga menimbulkan ketergantungan yang mendatangkan masalah.

\section{Internet Sebagai Media Pembelajaran}

Internet sebagai sumber informasi dapat digunakan untuk meningkatkan pengetahuan dan kemampuan sumber daya manusia. Kehadiran teknologi modern seperti internet telah membuat pandangan manusia mengenai kehidupan berubah. Paradigma komunikasi manusia dalam menjalankan aktivitas ekonomi, bisnis, interaksi sosial, dan politik menjadi berbeda. Sebelumnya manusia didominasi oleh aktivitas yang bersifat fisik 
yang dihalangi oleh keterbatasan. (Purbo, 1999 : 4). Namun dengan internet, ruang, jarak dan waktu yang membatasi manusia menghilang menurut Konichi Ohmae itulah dunia tanpa batas (the borderless world). (Mahayana, 1999: 97)

UNESCO Asia dalam artikel Developing and Using Indicators of ICT in Education mengatakan bahwa cukup penting untuk menguji indikator bahwa TIK tidak hanya digunakan sebagai alat dasar operasional tetapi juga sebagai alat komunikasi dalam rangka mengembangkan kreativitas, interaksi, collaborative learning (belajar kelompok), berpikir kritis dan memecahkan masalah (www.jurnalnasional.com).

Jadi internet memang akan bisa digunakan dalam seting pembelajaran di sekolah, karena memiliki karakteristik yang khas, yaitu (1) sebagai media interpersonal dan juga sebagai media massa yang memungkinkan terjadinya komunikasi oneto-one maupun one-to-many, (2) memiliki sifat interaktif, dan (3) memungkinkan terjadinya komunikasi secara sinkron (syncronous) maupun tertunda (asyncronous), sehingga memungkinkan terselenggaranya ketiga jenis dialog/komunikasi yang merupakan syarat terselengaranya suatu proses belajar mengajar.

\section{METODE PENELITIAN}

Penelitian ini bertujuan untuk mendeskripsikan dampak media internet dari para pelajar di Kota Purwokerto Kabupaten Banyumas Provinsi Jawa Tengah. Sedangkan metode penelitian yang digunakan dalam penelitian ini adalah kualitatif. Seperti yang dikemukakan oleh Bogdan dan Taylor (Moleong, 2007 : 4) yang mendefinisikan penelitian kualitatif sebagai prosedur penelitian yang menghasilkan data deskriptif berupa kata-kata tertulis atau lisan dari orangorang dan perilaku yang dapat diamati. Menurut mereka, pendekatan ini diarahkan pada latar dan individu tersebut secara holistik (utuh). Adapun pendekatan penelitian yang digunakan dalam penelitian ini adalah menggunakan penelitian deskriptif (Deskriptive Research), yang biasa disebut juga penelitian taksonomik (Taksonomic research), yang dimaksudkan untuk eksplorasi dan klarifikasi mengenai sesuatu fenomena atau kenyataan sosial, dengan jalan mendeskripsikan sejumlah variabel yang berkenaan dengan masalah dan unit yang diteliti. Jenis penelitian ini tidak sampai mempersoalkan jalinan hubungan antar variabel yang ada dan tidak dimaksudkan untuk menarik generasi yang menjelaskan variabel-variabel anteseden yang menyebabkan sesuatu gejala atau kenyataan sosial. Karenanya, pada suatu penelitian deskriptif, tidak menggunakan dan tidak melakukan pengujian hipotesis, seperti yang dilakukan untuk membangun dan mengembangkan perbendaraan teori. (Faisal, 2001:20)

Teknik sampling yang digunakan dalam penelitian ini adalah dengan sampling purposif (purposive sampling), peneliti memilih informan berdasarkan kriteria yang dianggap memenuhi tujuan penelitian. Pada penelitian ini yang menjadi informan adalah para aktivis pelajar yang berada di Sekolah Menengah Umum (SMU), Sekolah Menengah Keguruan (SMK) dan Madrasah Aliyah (MA) di Kota Purwokerto. Pertimbangannya, aktivis pelajar merupakan representasi dari para pelajar di komunitasnya yang dianggap bisa mewakili dan memiliki eksistensi, aktivitas dan peran yang lebih dominan. Namun dari dua puluh sekolah yang direncanakan hanya 12 sekolah yang mengirimkan delegasinya selama dua kali undangan FGD, yaitu Ketua Organisasi Pelajar Intra Sekolah (OSIS) antara lain SMAN 1, SMA 2, SMA Veteran, SMKN 1, SMKN 2, SMK Ksatrian, SMK Swagaya, SMK Telkom, SMK Wiworotomo, dan SMK 75, Sanggar Kegiatan Belajar (SKB), Madrasah Aliyah Negeri (MAN) 1 dan 2. Total informan menjadi 16 pelajar, karena ada sekolah yang mengirimkan 2 pelajar sebagai peserta FGD.

Kemudian analisis data sebagaimana menurut Abdurahman (2003 : 65) yang menyatakan bahwa analisis data berarti mengurai data atau menjelaskan data, sehingga berdasarkan data itu pada gilirannya dapat ditarik pengertian-pengertian serta 
kesimpulan-kesimpulan. Data tersebut bisa didapatkan dari data primer yaitu hasil wawancara dan Focus Group Discussion (FGD) dari informan. Kemudian dilengkapi dengan data sekunder yaitu dari dokumentasi yang dibutuhkan dalam penelitian. Adapun hasil pengumpulan data tersebut, kemudian dianalisis dengan: Pertama, reduksi data yaitu reduksi data diartikan sebagai proses pemilihan, pemusatan perhatian pada penyederhanaan, pengabstrakan, transformasi data kasar, yang muncul dari catatan-catatan lapangan. Hasil wawancara di lapangan penulis tuangkan dalam sebuah narasi yang kemudian disederhanakan dengan memilih hal-hal yang sejenis dan dibutuhkan serta mengelompokkannya sesuai pembahasan agar lebih mudah dalam penyajiannya.

Kedua, pelaksanaan focus group discussion (FGD) (dalam Bungin 2008: 138139) yaitu tahap pertama dengan diskusi yang melibatkan anggota FGD berdasarkan kemampuan dan kompetensi. Tahap dua, dengan analisis data Focus Group Discussion (FGD) yaitu : (1) Melakukan koding terhadap sikap dan pendapat pertama yang memiliki kesamaan. (2) Menentukan kesamaan sikap dan pendapat berdasarkan konteks yang berbeda. (3) Menentukan persamaan istilah yang digunakan termasuk perbedaan pendapat terhadap istilah yang sama tadi. Melakukan klasifikasi dan kategorisasi terhadap sikap dan pendapat peserta. (5) Mencari hubungan di antara masing-masing kategori yang ada untuk membentuk bangunan hasil diskusi. Kedua, penyajian data yaitu hasil penelitian dari wawancara dan Focus Group Discussion (FGD) dipaparkan secara deskriptif berdasarkan temuan di lapangan. Ketiga, penarikan kesimpulan.

\section{HASIL PENELITIAN DAN PEMBAHASAN}

\section{Pengenalan Pertama Penggunaan Media Internet}

Pengenalan internet pelajar ternyata rata-rata sudah mengenal sejak di tingkat SD dan SMP, yang secara dominan belajar sendiri dan dari praktikum di sekolah yaitu mata pelajaran Teknologi Informasi dan Komunikasi (TIK), kemudian ada juga yang pengalamannya diajari teman. Aplikasi internet yang digunakan pada awal pengenalan internet yaitu kebanyakan mempelajari atau menggunakan e-mail di Yahoo dan browsing dan searching di website lewat mesin pencari yang rata-rata menggunakan Google. Selebihnya ada yang menggunakan Yahoo Messanger (YM) untuk chatting.

Kemudian terjadi pergeseran dominasi penggunaan pelajar dalam aplikasi internet untuk saat ini (2010) yaitu lebih banyak menggunakan facebook dan youtube. Aplikasi lainnya yaitu email, chatting di Yahoo messager (YM) dan twitter, namun pengguna friendster sangat sedikit. Kalangan pelajar memang mengalami pengenalan bahwa media internet sebagai media pembelajaran, sehingga internet bisa dikatakan suatu tuntutan khususnya pelajaran wajib di sekolah yang diajarkan yaitu mata pelajaran TIK. Media internet juga sebagai suatu kebutuhan yang mengasyikan. Karena pola interaksi seperti pertemanan terjadi pergeseran yaitu lebih intens lewat media internet seperti komunikasi melalui facebook (FB) yang sangat booming untuk era sekarang (tahun 2010) sebagai aplikasi internet yang sangat menarik dan mengasyikan.

\section{Waktu dan Fasilitas Media Internet}

Dalam satu hari, pelajar lebih dominan menggunakan interet hanya jika penting saja, kemudian ada juga yang kadang-kadang di bawah 5 jam sehari. Ada juga yang punya pengalaman menggunakan internet lebih dari lima jam yaitu online game, walau saat ini tidak dilakukan lagi. Tempat untuk menggunakan internet pelajar kebanyakan dilakukan (1) warung internet (Warnet), (2) handphone (HP). Jadi pelajar saat ini memiliki akses internet di handphone-nya walau hanya sekedar digunakan untuk membuka facebook (FB) karena relatif murah bahkan gratis untuk jenis kartu GSM tertentu. (3) sekolah juga merupakan tempat yang biasa digunakan pelajar melakukan akses 
internet dengan fasilitas yang sudah tersedia di laboratorium komputer setiap sekolah, kecuali di sekolah Sanggar Kegiatan Belajar (SKB) Jl. Prof. Boenyamin Purwokerto belum tersedia. Sehingga pelajar mengakui kalau internet dirasakan sebagai media yang relatif terjangkau, tidak dianggap mahal. Namun sedikit yang menggunakan tempat Cafe dengan fasilitas wireless free hotspot area, dan sangat sedikit juga penggunaan di rumah karena masih banyak yang tidak punya akses internet.

Pelajar tidak secara dominan mengakui adanya warnet yang menjadi tempat langganan atau favoritnya, pertimbangan pilihan warnet kebanyakan memiliki kriteria yaitu murah, nyaman (ruang AC) dan dekat. Untuk tarif warnet sampai ada yang paling murah sebesar Rp. 1.500,- per jam hingga Rp. 3.500 ,- per jam, tergantung fasilitas warnet, kenyamanan dan kecepatan akses.

Pelajar sangat mengetahui warnet yang sangat tertutup (privat) seperti ruang pribadi yang orang lain tidak akan mengetahui mereka sedang melakukan aktivitas apa di dalam. Sebegitu pribadi dan rahasianya mengunduh atau menggunakan internet. Sehingga pelajar juga menyadari dan mengetahui bahwa warnet sering dijadikan tempat melakukan praktek pornografi baik mengunduh atau download gambar dan video atau sambil melakukan perbuatan "mesum" dengan pasangannya. Termasuk fasilitas internet yang menyuguhkan permainan dunia maya seperti online game yang menghabiskan waktu atau sampai lupa waktu dengan berjam-jam mengakses internet.

\section{Manfaat Media Internet}

Internet dijadikan media pembelajaran bagi pelajar masih dalam kategori mata pelajaran tertentu saja seperti kebanyakan dalam mata pelajaran Teknologi Informasi dan Komunikasi (TIK) untuk mengirim tugas dalam bentuk email. Kemudian mata pelajaran lainnya seperti kesenian, sejarah, PPKN, dan lain sebagainya, untuk mencari beberapa keperluan tugas dan referensi tertentu.

Bagi pelajar media internet dirasakan penting dan sebagian besar menganggap media internet sebagai (1) media hiburan (2) pembelajaran (3) pertemanan dan (3) sumber ilmu pengetahuan. Selebihnya menganggap media internet sebagai media refreshing dan aktualisasi. Sedangkan alasan menggunakan internet pelajar merasa bahwa (1) tuntutan belajar atau kebutuhan (2) murah dan mudah diakses di mana saja dan (3) hobi untuk kesenangan.

Sehingga pelajar menganggap media internet benar-benar sangat positif dan bermanfaat bagi mereka. Akan tetapi sangat disayangkan bahwa guru yang mengajarkan TIK bukan guru khusus tetapi merupakan guru yang juga mengajarkan mata pelajaran lainnya, dan ini terjadi di beberapa sekolah, bahkan ada yang merupakan guru Bimbingan Konseling (BK) dan karyawan Tata Usaha (TU).

\section{Dampak Media Internet dan Antisipasinya}

Adanya situs pornografi membuat pelajar menyetujui pembatasan bahkan pemblokiran situs-situs porno tersebut, karena hal tersebut akan menimbulkan pengaruh yang kurang baik bagi orang yang mengaksesnya. Situasi di warung internet yang tertutup akan memudahkan atau memungkinkan pengunjung untuk mengakses pornografi, apalagi para pengunjung warnet kebanyakan adalah pelajar yang secara psikologis masih mudah terpengaruh oleh halhal yang baru seperti pornografi misalnya. Namun informan mengaku bahwa mereka menyadari internet merupakan media yang tanpa batas, sehingga diperlukan kesadaran dari mereka sendiri yakni berupa kontrol diri.

Kemudian peran orang tua juga sangat besar dengan selalu mendampingi, mengingatkan dan mengontrol anaknya dalam menggunakan media internet. Minimal pelajar yang masih memiliki ketergantungan biaya dari orang tua selalu diberikan peringatan atau saran untuk tidak melakukan hal-hal negatif di dalam menggunakan internet. Termasuk guru di sekolah, ternyata masih ada yang memberikan nasihat dan batasan dalam mengaruhi dunia internet.

Hal-hal yang harus diperhatikan dalam 
penggunaan internet seperti : (a) Tidak memasang nama, profil lengkap, foto dan video sembarangan di internet; (b) berhatihati dalam mengekpresikan dan menyampaikan perasaan melalui internet jangan menyinggung unsur SARA. (c) selalu mengecek kebenaran informasi yang diterima melalui internet; (d) memutuskan komunikasi dengan orang asing yang tidak dikenal, apalagi melakukan pertemuan

\section{Konsep Warnet Sehat}

Para pelajar sangat mengetahui dan memahami kondisi warung internet sebagai tempat mengakses internet yang mudah, murah serta nyaman dan aman. Namun di sisi lain pelajar menyadari keadaan internet yang dalam kondisi yang sangat tertutup sekat bilik atau kamar bilik setiap ruang sehingga pengguna (konsumen) warnet tidak terlihat dari luar, begitu sangat privat atau sangat pribadi sekali ruang di warnet. Para pelajar mengakui terjadi penyalahgunaan media internet dengan mengunduh gambar atau video asusila secara mudah.

Para pelajar memahami warnet dalam kategori sehat, yaitu warnet dengan kriteria : Pertama, ada aturan jadwal tertentu untuk para pelajar, sehingga ketika jam sekolah kecuali hari libur sekolah pelajar tidak boleh masuk internet. Kedua, warnet dengan kamar bilik yang tidak terlalu tertutup. Ketiga, warnet yang memiliki software khusus untuk memblokir situs-situs tertentu. Konsep warnet sehat tersebut bisa diwujudkan dengan adanya peraturan mengenai ijin dan operasional warnet.

Perda ijin operasional warnet ini sangat penting sebagaimana dalam www.tribunpekanbaru.com edisi Senin 10 Mei 2010 yang berjudul "MUI Usul Perda Warnet", memberitakan bahwa "Menindaklanjuti maraknya perbuatan maksiat di warung internet (warnet) yang dilakukan pasangan muda-mudi dan pelajar, Majelis Ulama Indonesia (MUI) Kota Pekanbaru memberikan beberapa taushiyah atau rekomendasi. Ditujukan kepada pemilik warnet, Pemkot dan umat Muslim. Rekomendasi sebanyak enam lembar itu berisikan dalil-dalil dari ayat Al Qur'an dan hadist sebagai dasar keputusan MUI. Ditandatangani langsung Ketua MUI Kota Pekanbaru, Prof. Dr. Ilyas Husti dan Sekretaris Ridwan Hasbi, kemudian ditembuskan kepada walikota, DPRD, dan unsur Muspida. Rekomendasi pertama ditujukan kepada pengusaha warnet supaya membuat fasilitas terbuka, menghilangkan sekat tertutup, mengatur jadwal buka dari jam 08.00-22.00 dan melarang pelajar berseragam di jam sekolah. Terhadap Pemkot, MUI meminta supaya mengawasi dan membuat peraturan daerah (perda) tentang pengelolaan warnet.

Taushiyah terakhir ditujukan kepada umat muslim supaya mendidik generasi muda bertaqwa kepada Allah SWT. Menjadikan warnet hanya sebagai tempat mencari informasi. Turut memantau dan mengawasi warnet di lingkungan tempat tinggal.

\section{Perda Warnet}

Perda tentang ijin pendirian dan operasional warnet begitu penting untuk dibuat dan diberlakukan untuk mencegah maraknya kebablasan yang nyaris tidak bisa dibendung di dunia maya khususnya di warnet. Peraturannya berupa setiap warnet yang didirikan harus memenuhi ketentuan seperti: (1) Bentuk dan ketinggian dari Kamar Bilik Umum (KBU) yang tidak terlalu tertutup dengan hanya membatasi sampingnya saja sedang depannya tidak menggunakan pembatas, kalau pun menggunakan pembatas semua sisi KBU maka ketinggiannya cukup 1 meter saja dengan menggunakan kursi. Sedangkan untuk posisi lesehan dengan tidak menggunakan kursi maka ketinggian KBU hanya $80 \mathrm{~cm}$ s.d 1 meter. Atau bisa saja posisi duduk KBU di warnet saling membelakangi maka tidak ada pintu atau sekat yang di belakang KBU. (2) Warnet harus memiliki jam kunjungan yang disesuaikan dengan pelanggan, khusus pelajar maka tidak diperbolehkan pada jam aktivitas sekolah kecuali hari libur. Ijin untuk operasional maksimal hanya sampai jam 22.00 saja. (3) Warnet juga bisa memiliki software khusus yang dipasang di servernya 
untuk memblokir situs-situs tertentu yang bisa merusak moral generasi muda, seperti software K9 Web Protection (www.k9webprotection.com), kemudian website filter situs negatif di internet oleh DNS Nawala Project alamatnya www.nawala.org.

Kesehatan berinternet tidak cukup hanya dengan pendekatan teknologi dengan pemblokiran oleh software tertentu dan filter situs negatif seperti oleh DNS Nawala, kemudian juga tidak cukup jika diserahkan kepada pengawasan dan evaluasi orang tua terhadap anak. Akan tetapi juga perangkat hukum yang harus bisa ditegakkan dalam tataran implementasi di daerah yaitu berupa peraturan daerah (Perda). Jadi kepedulian pemerintah khususnya Kementerian atau Dinas Komunikasi dan Informatika tidak juga hanya sebatas sosialisasi internet aman dan sehat, tetapi sudah merancang dan merangsang peraturan di level daerah berupa perda.

\section{KESIMPULAN}

Media internet dikenal pertama kali oleh para pelajar di bangku Sekolah Menengah Pertama (SMP) secara teori pada Kelas 1 (satu) dan praktek internet pada Kelas 2 (dua) yaitu pada materi pelajaran Teknologi Informasi dan Komunikasi (TIK).

Aplikasi pertama yang dikenal sekali dipelajari adalah membuat email di Yahoo dan melakukan pencarian informasi di website mesin pencari yang bernama Google.

Para pelajar memaknai internet sebagai media pembelajaran dan sumber pengetahuan khususnya dalam membantu kebutuhan tugas di sekolah. Aplikasi email sering digunakan untuk mengirimkan tugas kepada gurunya khususnya mata pelajaran TIK.

Pelajar menggunakan aplikasi internet paling dominan adalah Facebook (FB) dan Yahoo Messanger (YM) karena sudah menjadi pola interaksi masa kini yang menarik, praktis dan ekonomis. Sampai bisa dilakukan di fasilitas handphone (HP) yang semua pelajar memilikinya, diakui sangat murah dan mudah bahkan ada karu GSM yang memberikan fasilitas gratis untuk aplikasi internet tersebut.

Semua sekolah para pelajar sudah memiliki akses wireless hotspot area di laboratorium sekolahnya, kecuali di sekolah Sanggar Kegiatan Belajar (SKB)

Para pelajar mengetahui warung internet (Warnet) yang sangat tertutup tempatnya yaitu di sekat seperti bilik-bilik kamar, sampai ke warnet yang disebut warnet sehat, yaitu yang tempatnya tidak tertutup oleh sekat-sekat kamar.

Mengetahui dan menyadari dampak media internet khususnya mengenai dampak negatif seperti mengunduh pornografi sampai terjadi tindakan pornografi di warnet.

Pelajar menyadari kalau berinternet tergantung pada kontrol dirinya dan peran orang tua. Juga menyetujui adanya pembatasan situs-situs tertentu yang berdampak negatif.

Pihak sekolah harus proaktif dalam memberikan sosialisasi secara rutin mengenai dampak media internet khususnya pada mata pelajaran TIK, selain keahlian teknis juga kesadaran akan dampaknya.

Pihak sekolah sudah harus digalakkan akses internet sehat dengan menggunakan software khusus untuk memblokir situs-situs tertentu di laboratorium komputer atau area lingkungan sekolah.

Pemerintah dan wakil rakyat di daerah harus cepat tanggap dan peduli terhadap dampak media internet, mengingat telah adanya Undang-undang Pornografi serta UU Informasi dan Transaksi Elektronik. Sehingga harus memiliki peraturan daerah (Perda) untuk menciptakan gerakan warnet sehat, seperti aturan sekat pembatas berupa Kamar Bilik Umum (KBU) yang tidak terlalu tertutup dan aturan jam layanan untuk pelajar, serta ada software khusus memblokir situssitus pornografi. Sehingga warnet benar-benar menjadi tempat jasa yang bersifat umum bukan sangat pribadi.

Faktor orang tua dan kontrol keluarga untuk mendampingi masih sangat efektif dalam memantau anak (palajar) menggunakan media internet.

Perlu ada riset lanjutan mengenai dampak media internet dengan metode action 
research. Hasilnya bisa dijadikan program kampanye dan sosialisasi secara periodik di kalangan pelajar mengenai dampak media internet yang bekerjasama antara pihak sekolah, orang tua dan pemerintah daerah.

\section{DAFTAR PUSTAKA}

Abdurahman, Dudung. 2003. Pengantar Metode Penelitian. Yogyakarta: Kurnia Kalam Semesta.

Arifin, Anwar. 2003. Komunikasi Politik : Paradigma - Teori - Aplikasi Strategi dan Komunikasi Politik Indonesia. Jakarta : PT. Balai Pustaka.

Baldwin, John R, Perry, S.D \& Moffit M.A.. 2004. Communication Theories for Everyday Life. Boston : PE.Inc.

Baran, Stanley J \& Davis, Dennis K. 2003. Mass Communication Theory: Foundation, Ferment, and Future 3th ed. Balmont : Wadsworth Publishing.

Bungin, Burhan. 2008. Analisis Data Penelitian Kualitatif : Pemahaman Filosofis dan Metodologis ke Arah Penguasaan Model Aplikasi. Jakarta : Rajawali Pers.

Effendy, Onong Uchjana. 2005. Ilmu Komunikasi : Teori dan Praktek, Bandung : Rosdakarya.

Faisal, Sanapiah. 2001. Format-format Penelitian Sosial. Jakarta : PT Raja Grafindo Persada.

Littlejohn, Stephen. W. 1996. Theories of Human Communication. USA: Wadsworth Publishing Company.
Mahayana, Dimitri. 1999. Menjemput Masa Depan. Bandung : PT. Remaja Rosdakarya.

McQuail, Dennis. 1987. Teori Komunikasi Massa. Jakarta : Penerbit Erlangga.

Nurudin. 2004. Komunikasi Massa. Malang : Cespur.

Purbo, Ono. W. 1999. Teknologi Warung Internet. Jakarta : PT. Elex Media Komputindo.

\section{Sumber lainnya :}

Athari, Nonni, Sri. 2004. "Internet Addiction Disorder : Pengaruhnya terhadap Kehidupan Akademik, Sosial dan Keuangan, serta Karakteristik Khalayak Mahapelajar yang Mengalaminya". Jurnal Thesis. Departemen Ilmu Komunikasi FISIP Universitas Indonesia, Volume III No. 1.

Buku Internet Sehat : Pedoman Ber-Internet yang Aman, Nyaman dan Bertanggungjawab. Jakarta : Kementerian Komunikasi dan Informatika (Kominfo) dan Indonesia ICT for Partnership (ICT Watch)

Ratnasari, Anne. "Internet sebagai Media Penunjang Studi Mahapelajar" dalam "Mimbar" : Jurnal Sosial dan Pembangunan. Volume XXIV. No 1, (Januari - Juni 2008) ISSN 02158175

\section{Internet :}

www.jurnalnasional.com 